\title{
Effects of frequency of supplementation with soyabean meal and litter size on performance of Angora does consuming low quality forage in late gestation and early lactation
}

\author{
R. Joemat ${ }^{1,2,4}$, A. L. Goetsch ${ }^{1,5}$, T. Wuliji ${ }^{1}$, G. W. Horn ${ }^{2}$, T. Sahlu ${ }^{1}$, \\ R. Puchala ${ }^{1}$, R.C. Merkel ${ }^{1}$, S. Soto-Navarro ${ }^{1}$ and M. Smuts ${ }^{3}$
}

\author{
${ }^{I} E$ (Kika) de la Garza American Institute for Goat Research, \\ Langston University \\ P.O. Box 730, Langston, Oklahoma, 73050, USA \\ ${ }^{2}$ Animal Science Department, Oklahoma State University \\ Stillwater, Oklahoma, 74078, USA \\ ${ }^{3}$ Centre for Animal Nutrition, \\ Agriculture Research Council - Animal Nutrition and Products Institute \\ Private Bag X2, Irene, 1675, South Africa
}

(Received 18 March 2003; revised version 11 July 2003; accepted 28 October 2003)

\section{ABSTRACT}

Angora does $(56 ; 43 \pm 0.7 \mathrm{~kg}$ initial body weight $(\mathrm{BW}))$ consuming low quality forage, with single- or twin-kid litters, were used in a 120-day experiment (15 8-day periods) to determine effects of frequency of supplementation with soyabean meal (SBM) on performance in late gestation $(92 \pm 18$ days in gestation initially) and early lactation. Prairie hay (crude protein 5.1\% and neutral detergent fibre $70 \%$ ) was consumed ad libitum without SBM (C), or SBM was offered at an average daily rate of $0.125 \%$ BW every 1,4 or 8 days (1X, $4 \mathrm{X}$ and $8 \mathrm{X}$, respectively). Ground maize was supplemented after kidding at $0.5-1.0 \% \mathrm{BW}$, and kidding was in periods $7-11$, with approximately one-half of the does kidding before day 58. Average total dry matter intake over the entire experiment was lowest among treatments $(\mathrm{P}<0.05)$ for $\mathrm{C}(1.00,1.25,1.24$ and $1.23 \mathrm{~kg}$ /day $)$, and average forage intake was $0.79,0.97,0.96$ and $0.94 \mathrm{~kg} /$ day for $\mathrm{C}, 1 \mathrm{X}, 4 \mathrm{X}$ and $8 \mathrm{X}$, respectively $(\mathrm{SE}=0.39)$. Body weight on day 31 was lower $(\mathrm{P}<0.05)$ for $\mathrm{C}$ vs X1, X4 and X8 $(43.3,46.0,46.2$ and $45.9 \mathrm{~kg}$, respectively). On day 57 , BW was lower $(\mathrm{P}<0.05)$ for $\mathrm{C}$ and $8 \mathrm{X}$ vs $1 \mathrm{X}$ and $4 \mathrm{X}(37.7,41.5,41.8$ and $39.3 \mathrm{~kg})$, and ranked $(\mathrm{P}<0.05) \mathrm{C}<8 \mathrm{X}<1 \mathrm{X}$ and $4 \mathrm{X}$ on day $120(31.5,38.5,37.7$ and $34.7 \mathrm{~kg}$ for $\mathrm{C}$ vs $\mathrm{X} 1$, $\mathrm{X} 4$ and $\mathrm{X} 8$, re-

\footnotetext{
${ }^{4}$ A graduate fellowship for the first author was providedby the USDA Agricultural Research Service and for the USDA/SANPAD Project provided resource support

${ }^{5}$ Corresponding author: e-mail: goetsch@luresext.edu
} 
spectively). Does with single kids had greater $(\mathrm{P}<0.05) \mathrm{BW}$ than twin-bearing does on day 57 (41.5 vs $39.7 \mathrm{~kg}$ ) and 120 (37.3 vs $33.9 \mathrm{~kg}$ ). There were no differences among supplement treatments or between litter sizes in mohair fibre yield, diameter, length or staple strength. Clean fibre growth rate was similar between litter sizes on day 1-57 and 58-120 and among supplement treatments on day 1-57. However, on day 58-120 fibre growth rate was greater $(\mathrm{P}<0.05)$ for $1 \mathrm{X}$ compared with $\mathrm{C}$ and $4 \mathrm{X}\left(0.061,0.089,0.060\right.$ and $0.079 \mathrm{~g} / \mathrm{day} / 100 \mathrm{~cm}^{2}$ for $\mathrm{C}$ vs X1, $\mathrm{X} 4$ and $\mathrm{X} 8$, respectively). In conclusion, infrequent supplementation with SBM of Angora does consuming low quality forage, such as once every 8 days, may be as effective as supplementation daily or every 4 days with moderate nutrient requirements of late gestation. However, to maintain BW and perhaps stimulate mohair fibre growth, daily supplementation may be necessary in lactation regardless of litter size.

KEY WORDS: Angora goats, mohair, supplementation

\section{INTRODUCTION}

Ruminants often consume forages low in digestibility and protein, particularly in developing countries during the dry season. To achieve desirable levels of animal performance, feedstuffs high in crude protein $(\mathrm{CP})$ can be supplemented. However, in addition to the high cost of feedstuffs rich in $\mathrm{CP}$, considerable labour is required with daily supplementation. Therefore, infrequent supplementation is of interest to livestock producers if performance is not markedly adversely affected.

There are many reports of acceptable performance by beef cattle with infrequent supplementation of feedstuffs high in CP. However, there have been less studies concerning effects with fibre-producing ruminants, in particular Angora goats that can exhibit greater fibre growth relative to body weight (BW) than sheep highly selected for wool growth (Litherland and Sahlu, 1996). One of the few reports is that of Calhoun et al. (1988), in which supplementation of male Angora goats consuming low quality forage with cottonseed meal every 1,2,3, 4 or 5 days did not influence mohair fleece production or fibre diameter. However, it is unknown if similar findings would occur with higher nutritional requirements of does in late gestation and lactation. Likewise, litter size also impacts nutrient needs. Therefore, objectives of this experiment were to determine effects of frequency of supplementation with soyabean meal on performance of Angora does consuming low quality forage in late gestation and early lactation with single- or twin-kid litters.

\section{MATERIAL AND METHODS}

\section{Animals and treatments}

Fifty-six mature Angora does $(43 \pm 0.7 \mathrm{~kg}$ initial BW) were initially used in the 120-day experiment (15 8-day periods), which began on January 12 and ended 
May 10, 2000. Angora bucks were placed with does from October 3 to November 12, 1999. Pregnancy and litter size were tested by ultrasonography. At $92 \pm 18$ days of gestation, does were allocated to eight groups (two groups per treatment), with similar means and variation within group and litter size (single or twin) for projected birth date and BW. Does were placed in eight $4 \times 10 \mathrm{~m}$ pens. For the first 3 days after kidding, does and kids were moved to small temporary pens.

TABLE 1

Composition of feedstuffs consumed by Angora does, dry matter, $\%$

\begin{tabular}{lccc}
\hline Item & $\begin{array}{c}\text { Prairie } \\
\text { hay }\end{array}$ & $\begin{array}{c}\text { Soyabean } \\
\text { meal }\end{array}$ & $\begin{array}{c}\text { Ground } \\
\text { maize }\end{array}$ \\
\hline Ash & 5.0 & 9.2 & 1.4 \\
Crude protein & 5.1 & 45.3 & 7.2 \\
Neutral detergent fibre & 69.8 & 16.4 & 15.2 \\
Acid detergent fibre & 49.1 & 10.3 & 4.8 \\
Acid detergent lignin & 14.8 & 3.5 & 3.8 \\
\hline
\end{tabular}

Coarsely chopped prairie hay was offered daily in wooden feeders ad libitum (Table 1). The amount of hay offered was such that the amount remaining the next morning would be approximately $110 \%$ of that offered, in order to minimize selection. All does had free access to fresh water and trace mineralized salt blocks. On the last day of each 8-day period, orts were removed and weighed. Does were supplemented with soyabean meal (SBM) in separate feeders. Dietary treatments were no supplementation with SBM (C) and supplementation with SBM daily $(1 \mathrm{X})$ or every $4(4 \mathrm{X})$ or 8 days $(8 \mathrm{X})$. For the $4 \mathrm{X}$ treatment, SBM was offered on day 1 and 5 of the 8 -day periods, and was given on day 1 for $8 X$. The daily rate of SBM feeding for $1 \mathrm{X}, 4 \mathrm{X}$ and $8 \mathrm{X}$ was $0.125 \% \mathrm{BW}(\mathrm{DM})$; therefore, on days of supplementation $1 \mathrm{X}, 4 \mathrm{X}$ and $8 \mathrm{X}$ does received $0.125,0.5$ and $1.0 \% \mathrm{BW}$, respectively. In addition to SBM, after the first doe kidded on February 28 (day 49 in period 7), all does were supplemented with ground maize at $0.5 \% \mathrm{BW}$. Because of low doe BW and BW of kids at birth, the daily level of supplemental maize was increased from 0.5 to $1.0 \% \mathrm{BW}$ on March 16 (day 65 in period 9) until the end of the experiment. It was initially planned to supplement does only after kidding until the end of the experiment with $0.5 \% \mathrm{BW}$ of maize via temporary separation of gestating and lactating does within pens until all does had kidded. The changes were necessary because of lower hay quality than expected based on a sample and analyses conducted prior to the experiment.

Does were treated for internal parasites (4 mL Ivomec; Merck Ag Vet Division, Rahway, NJ) on January 19 and received vaccinations on January 19 and February 28 for Corynebacterium pseudotuberculosis $(2.5 \mathrm{ml} \mathrm{U}$-Bac 8; Colorado Serum Co., Denver, CO). Kids received $2 \mathrm{ml}$ of $\mathrm{CD}$ and $\mathrm{T}$ vaccine (Colorado Serum, Co., Denver, CO) on May 10. 


\section{Measurements}

Does were weighed on day 0,31 and 57, immediately after kidding and on day 120. On day 31 none of the does had kidded, whereas on day 57 approximately $50 \%$ had kidded; day 120 was 4 wk after the last doe had kidded. Kids were weighed at birth and on day 120 .

Feedstuffs were grab sampled at the beginning of each 8-day period. Does were shorn $2 \mathrm{wk}$ before and $2 \mathrm{wk}$ after the experiment, and fleece was sampled. In addition, a $100 \mathrm{~cm}^{2}$ patch on the left mid-side was clipped (Oster blade no. 40) on day 0,57 and 120 to determine mohair growth and yield. Skin biopsy samples were taken close to the site of fibre patch samples with local anaesthesia at these times as well. Tissue samples were placed in cassettes and preserved in phosphate buffered formalin for a minimum of $48 \mathrm{~h}$ before analysis.

Ruminal fluid was sampled by stomach tube and blood via jugular venipuncture in periods 4 and 12 at approximately $4 \mathrm{~h}$ after feeding. All does were sampled on day 1 of the period, which was the day of supplementation for 1X, $4 \mathrm{X}$ and $8 \mathrm{X}$. The day of the period for sampling $\mathrm{C}$ and $1 \mathrm{X}$ was not anticipated to influence ruminal fluid ammonia $\mathrm{N}$ or blood urea $\mathrm{N}$ or glucose concentrations. Conversely, to address likely differences among days for $4 \mathrm{X}$ and $8 \mathrm{X}$, additional samples were taken on day 4 for $4 \mathrm{X}$ and $8 \mathrm{X}$ ( 3 days after supplementation) and day 7 for $8 \mathrm{X}$ (6 days after supplementation). Ruminal fluid $(2 \mathrm{ml})$ was placed in a tube with 3 $\mathrm{ml}$ of $3 \mathrm{~N} \mathrm{HCl}$ and frozen at $-20^{\circ} \mathrm{C}$ until analysis. Blood was collected in a tube containing heparin, chilled in ice for approximately $1 \mathrm{~h}$ and centrifuged at $1500 \times$ $g$ for $25 \mathrm{~min}$ at $4^{\circ} \mathrm{C}$.

\section{Analyses}

Feedstuffs were dried at 55EC for $48 \mathrm{~h}$, ground in a Wiley mill to pass a $1 \mathrm{~mm}$ screen and anlaysed for DM, ash (AOAC, 1990), CP (Technicon Instrument Co., Tarrytown, NY), neutral detergent fibre, acid detergent fibre and acid detergent lignin (filter bag technique; ANKOM Technology Corp., Fairport, NY). Ruminal fluid was analysed for ammonia by the phenol-hypochlorite colorimetric procedure of Broderick and Kang (1980). Plasma was analysed for glucose and urea $\mathrm{N}$ via colorimetric assays with a Technicon AutoAnalyzer II System (Technicon Instruments, Tarrytown, NY).

Mohair patch samples were weighed and used to determine scoured (clean) yield and fibre diameter. Clean yield was calculated with a $11.23 \%$ adjustment for plant material not removed by scouring (ASTM, 1988). Fibre diameter was measured with patch samples using an optical fibre distribution analyzer (OFDA 100; Zellweger Uster, Inc., Charlotte, NC). Clean staple length and strength were determined for fleece sampled on day 120 , since patch samples were too short for 
analyses. Clean staple length was determined by standard procedures of ASTM (1988). Clean staple strength was determined using an Agritest Staple Breaker System (Agritest Pty., Sydney, Australia) at the San Angelo Texas A and M University Research Station. Staple strength was analysed as the maximum load (Newtons) required to break a staple. To correct for differences in the size of staple tested, measures were standardized by linear density $(\mathrm{g} / \mathrm{cm}=$ kilotex $)$.

Skin biopsy samples were subjected overnight to a 12-step process of graded concentrations of ethanol, chloroform, xylene and paraffin wax using a Citadel tissue processor (Shandon Inc., Pittsburg, PA). After the final step, samples were immediately embedded with the epidermal surface uppermost into a mold of paraffin-polymer wax using a Histocenter II Embedder (Shandon Inc.). The embedded skin was transversely sectioned into $8-\mu \mathrm{m}$ thick layers of wax ribbons starting from the epidermal surface to the base of hair follicles. Section samples were mounted on slides with at least five sectioned samples per slide. The mounted samples were stained using the adapted Sacpic stain method (Nixon, 1993). Approximately 10 follicle bundles were scored for number of active and inactive primary and secondary follicles, allowing estimation of follicle density and percentages of active and inactive primary and secondary follicles (Nixon, 1993).

\section{Statistical analyses}

Most data were analysed as a split-split-plot design, with a main plot of dietary treatment, subplot of litter size and sub-sub-plot of production state or phase (i.e. gestation and lactation) or day of measurement using MIXED model procedures for repeated measures (Littell et al., 1996). Models consisted of supplementation frequency, litter size, phase or day and all interactions; random sources of variation were group within supplementation frequency and animal within group. Although, for staple strength and length determined on fleece harvested at the end of the experiment, phase and interactions involving phase were dropped from the model, and terms with litter size were dropped from models for feed intake. Also, measures on day 0 , such as doe BW and skin measures, were used as covariates. For ruminal fluid and blood measures on different days of periods, mean values and those for day 1 were analysed as described above. To assess differences between or among days for $4 \mathrm{X}$ and $8 \mathrm{X}$ does, data were analysed within treatment with a model consisting of litter size, phase, day and all interactions; the random effect was group. Means were separated by least significant difference when overall F-values were significant $(\mathrm{P}<0.05)$.

Because of differences in levels of supplemental maize between phases of the experiment, separate supplementation frequency and litter size means and SE are presented for the different phases or days. When interactions involving sup- 
plementation frequency and litter size were significant, interaction means were presented; main effects were listed with nonsignificant interactions regardless of significance.

\section{RESULTS}

\section{Feed intake}

Total and forage intakes were similar among treatments in gestation (periods 1-6), during kidding (periods 7-11) and after all does had kidded and were lactating (periods 12-15; Table 2). Although differences were not significant, during each segment (i.e. periods 1-6, 7-11 and 12-15) total intake was numerically greater with than without SBM supplementation. In this regard, average total intake during the entire experiment was lowest among treatments for $\mathrm{C}(\mathrm{P}<0.05)$.

TABLE 2

Effects of supplementation frequency and production state on DM intake by Angora does, $\mathrm{kg} /$ day

\begin{tabular}{llccccc}
\hline \multirow{2}{*}{ Item } & \multirow{2}{*}{ Production state $^{2}$} & \multicolumn{5}{c}{ Supplementation frequency $^{1}$} \\
\cline { 3 - 6 } & & $\mathrm{C}$ & $1 \mathrm{X}$ & $4 \mathrm{X}$ & $8 \mathrm{X}$ & $\mathrm{SE}$ \\
\hline Forage & Gestation & 0.97 & 1.05 & 1.01 & 1.08 & 0.052 \\
& During kidding & 0.68 & 0.85 & 0.85 & 0.76 & 0.047 \\
& Lactation & 0.71 & 1.03 & 1.02 & 0.99 & 0.083 \\
& Mean & 0.79 & 0.97 & 0.96 & 0.94 & 0.057 \\
& & & & & \\
\multirow{2}{*}{ Total } & Gestation & 0.97 & 1.11 & 1.07 & 1.14 & 0.052 \\
& During kidding & 0.98 & 1.23 & 1.25 & 1.13 & 0.061 \\
& Lactation & 1.07 & 1.42 & 1.41 & 1.41 & 0.095 \\
& Mean & $1.00^{\mathrm{a}}$ & $1.25^{\mathrm{b}}$ & $1.24^{\mathrm{b}}$ & $1.23^{\mathrm{b}}$ & 0.042 \\
\hline
\end{tabular}

${ }^{\mathrm{ab}}$ means in a row without a common superscript letter differ $(\mathrm{P}<0.05)$

${ }^{1} \mathrm{C}=$ no supplementation with soyabean meal; $1 \mathrm{X}=$ daily supplementation with $0.125 \% \mathrm{BW}(\mathrm{DM})$ of soyabean meal; $4 \mathrm{X}=$ supplementation every fourth day with $0.5 \% \mathrm{BW}(\mathrm{DM})$ of soyabean meal; $8 \mathrm{X}=$ supplementation every eighth day with $1 \% \mathrm{BW}(\mathrm{DM})$ of soyabean meal

${ }^{2}$ the experiment consisted of 158 -day periods; gestation = periods 1-6; during kidding = periods 7-11 (approximately one-half of the does had kidded on day 57 in period 8); lactation = periods 12-15

Body weight

Doe $\mathrm{BW}$ was lowest among treatments for $\mathrm{C}$ throughout the experiment $(\mathrm{P}<0.05$; Table 3$)$. However, the difference increased in magnitude as the experiment progressed. Does on $1 \mathrm{X}$ and $4 \mathrm{X}$ treatments had similar BW at all times. Conversely, on day 57 and $120 \mathrm{BW}$ of $8 \mathrm{X}$ does was slightly less than for $1 \mathrm{X}$ and $4 \mathrm{X}$ does $(\mathrm{P}<0.05)$. It is unclear why a similar difference did not exist in $\mathrm{BW}$ after 
kidding, since about $50 \%$ of does had kidded on day 57 and birth weight of kids for $8 \mathrm{X}$ was not different from that of $1 \mathrm{X}$ and $4 \mathrm{X}$. Final kid BW was similar among treatments. Doe BW was similar between litter sizes on day 31 , although on day 57 and $120 \mathrm{BW}$ was greater for does with singles vs twins $(\mathrm{P}<0.05)$.

TABLE 3

Effects of supplementation frequency and litter size on BW $(\mathrm{kg})$ of Angora does and kids

\begin{tabular}{|c|c|c|c|c|c|c|c|c|}
\hline \multirow{2}{*}{ Item $^{2}$} & \multicolumn{4}{|c|}{ Supplementation frequency ${ }^{1}$} & \multirow{2}{*}{$\mathrm{SE}$} & \multicolumn{2}{|c|}{ Litter size } & \multirow{2}{*}{ SE } \\
\hline & $\mathrm{C}$ & $1 \mathrm{X}$ & $4 X$ & $8 \mathrm{X}$ & & 1 & 2 & \\
\hline \multicolumn{9}{|l|}{ Doe BW } \\
\hline day 31 & $43.3^{\mathrm{a}}$ & $46.0^{\mathrm{b}}$ & $46.2^{\mathrm{b}}$ & $45.9^{\mathrm{b}}$ & 0.74 & 45.4 & 45.2 & 0.53 \\
\hline day 57 & $37.7^{\mathrm{a}}$ & $41.5^{\mathrm{b}}$ & $41.8^{\mathrm{b}}$ & $39.3^{\mathrm{a}}$ & 0.75 & $41.5^{\mathrm{b}}$ & $38.7^{\mathrm{a}}$ & 0.53 \\
\hline after kidding & $34.6^{\mathrm{a}}$ & $39.2^{\mathrm{b}}$ & $38.3^{\mathrm{b}}$ & $38.6^{\mathrm{b}}$ & 1.17 & 38.4 & 37.0 & 0.82 \\
\hline day 120 & $31.5^{\mathrm{a}}$ & $38.5^{\mathrm{c}}$ & $37.7^{\mathrm{c}}$ & $34.7^{\mathrm{b}}$ & 0.84 & $37.3^{\mathrm{b}}$ & $33.9^{\mathrm{a}}$ & 0.60 \\
\hline change, day $1-120$ & $-11.9^{a}$ & $-5.4^{\mathrm{c}}$ & $-5.6^{c}$ & $-9.1^{b}$ & 0.83 & $-6.4^{b}$ & $-9.6^{a}$ & 0.58 \\
\hline \multicolumn{9}{|l|}{ Kid BW } \\
\hline birth & 2.5 & 2.6 & 3.1 & 2.9 & 0.12 & $3.2^{\mathrm{b}}$ & $2.3^{\mathrm{a}}$ & 0.08 \\
\hline final & 5.7 & 6.5 & 6.7 & 6.8 & 0.44 & $7.3^{\mathrm{b}}$ & $5.5^{\mathrm{a}}$ & 0.31 \\
\hline
\end{tabular}

abc means in a row without a common superscript letter differ $(\mathrm{P}<0.05)$

${ }^{1} \mathrm{C}=$ no supplementation with soyabean meal; $1 \mathrm{X}=$ daily supplementation with $0.125 \% \mathrm{BW}$ (DM) of soyabean meal; $4 \mathrm{X}=$ supplementation every fourth day with $0.5 \% \mathrm{BW}(\mathrm{DM})$ of soyabean meal; $8 \mathrm{X}=$ supplementation every eighth day with $1 \% \mathrm{BW}(\mathrm{DM})$ of soyabean meal

2 the experiment consisted of 158 -day periods; gestation = periods $1-6$; during kidding $=$ periods 7-11 (approximately one-half of the does had kidded on day 57 in period 8); lactation = periods $12-15$

\section{Mohair and skin follicles}

There were no differences among treatments or between litter sizes in mohair fibre yield, diameter, length or strength (Table 4). Patch fibre growth was similar between litter sizes on day 1-57 and 58-120 and similar among supplementation frequency treatments on day 1-57. However, on day 58-120 fibre growth rate was greater for $1 \mathrm{X}$ compared with $\mathrm{C}$ and $4 \mathrm{X}(\mathrm{P}<0.05)$, and the mean for $8 \mathrm{X}$ was intermediate $(\mathrm{P}>0.05)$. Skin follicle densities, activity of primary and secondary follicles and the primary:secondary follicle ratio were similar among supplementation frequencies and between litter sizes.

\section{Ruminal fluid ammonia $N$ and plasma urea $N$ and glucose concentrations}

The mean concentration of ammonia $\mathrm{N}$ in ruminal fluid during gestation was lower $(\mathrm{P}<0.05)$ for $\mathrm{C}$ than for $4 \mathrm{X}$ and $8 \mathrm{X}$, although mean concentrations for $4 \mathrm{X}$ and $8 \mathrm{X}$ are 


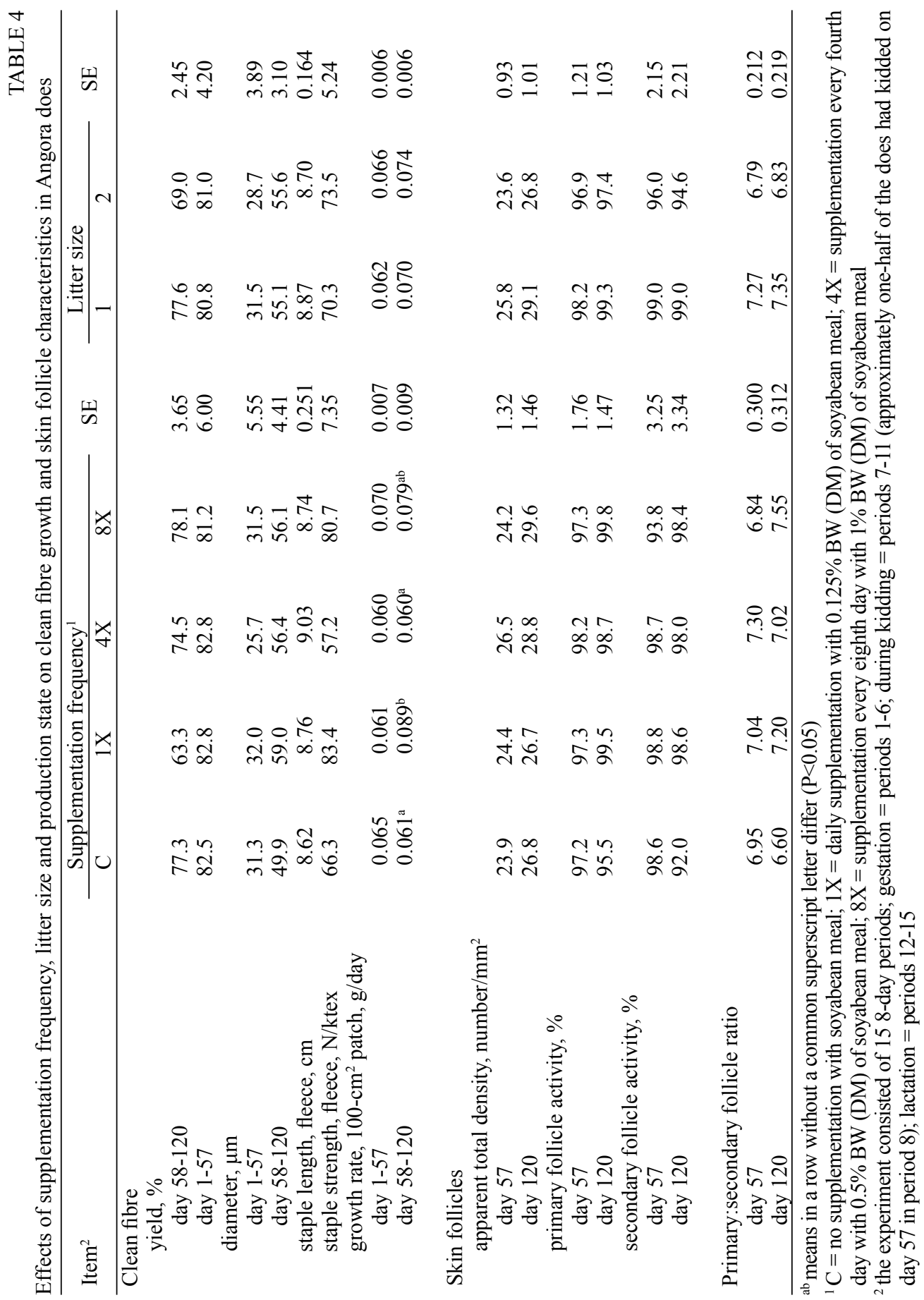




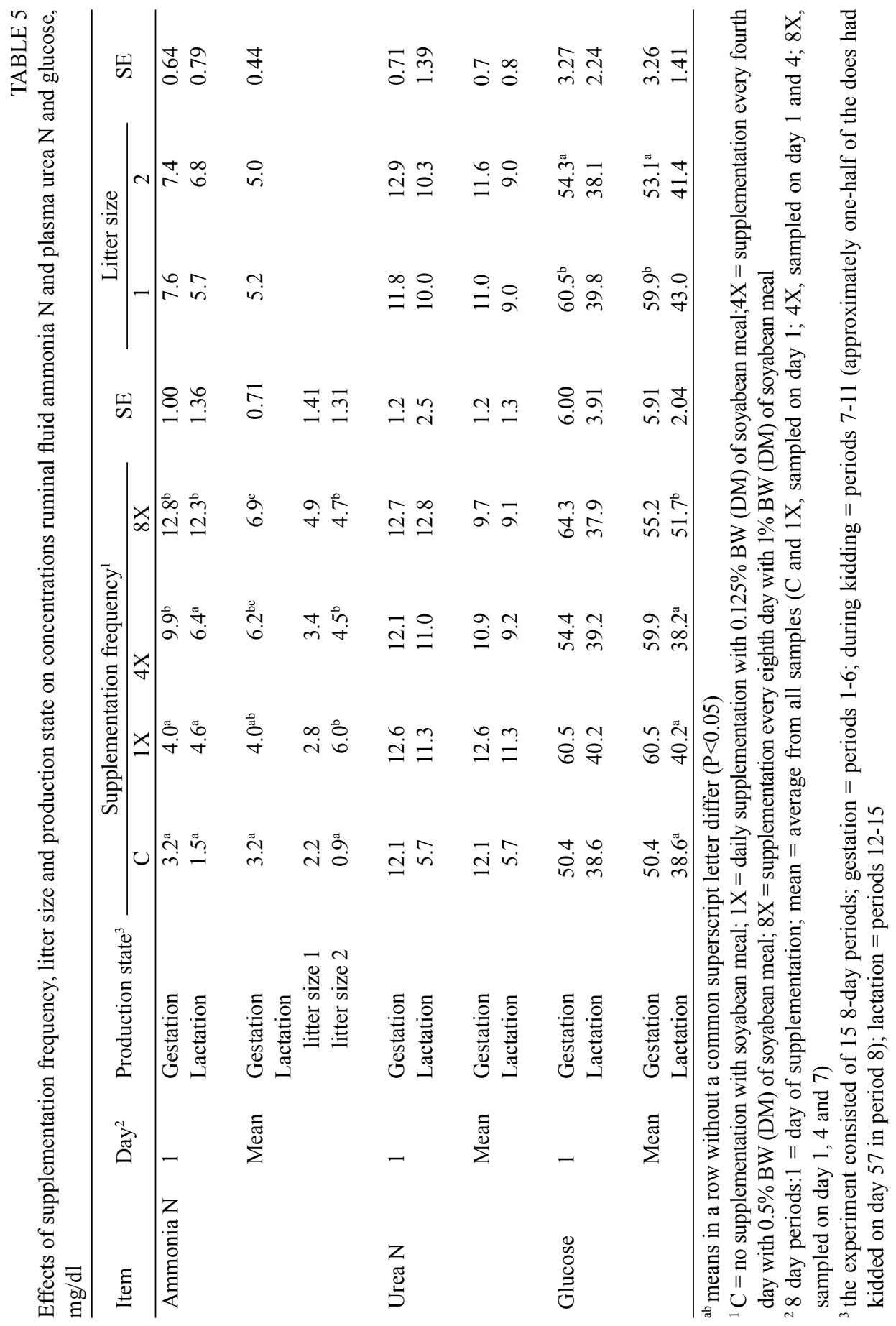


largely influenced by the particular days chosen for sampling (Table 5). There was an interaction between supplementation frequency and litter size $(\mathrm{P}<0.05)$ in mean ammonia $\mathrm{N}$ concentration during lactation. Mean concentration was similar among treatments for does with single kids. However, the concentration for does with twin kids was lowest among treatments for $\mathrm{C}(\mathrm{P}<0.05)$. On day 1 of gestation and lactation, when all treatment groups were supplemented, ruminal ammonia $\mathrm{N}$ concentration was similar between $\mathrm{C}$ and $1 \mathrm{X}$. This was somewhat surprising considering greater $\mathrm{CP}$ intake for $1 \mathrm{X}$. Although, samples were taken $4 \mathrm{~h}$ after feeding, which may have been later than the peak in concentration resulting from degradation of protein of SBM. Because of the high amount of SBM fed on day 1 for $8 X$, ammonia $\mathrm{N}$ concentration was greater $(\mathrm{P}<0.05)$ than for $\mathrm{C}$ and $1 \mathrm{X}$ in both gestation and lactation, but was similar to the concentration for $4 \mathrm{X}$ in gestation. Litter size did not influence ammonia $\mathrm{N}$ concentration on day 1 or mean concentration in gestation. On day 4 of the period, during both gestation and lactation, ruminal ammonia $\mathrm{N}$ concentration for $4 \mathrm{X}$ was less $(\mathrm{P}<0.05)$ than on day 1 (gestation: 9.9 vs $2.4 \mathrm{mg} / \mathrm{dl}$, $\mathrm{SE}=1.40$; lactation: 6.4 vs $1.8 \mathrm{mg} / \mathrm{dl}$ for day 1 and 4 , respectively). Similar findings were observed for $8 X$, with levels on day 4 and 7 not different but lower $(\mathrm{P}<0.05)$ than on day 1 of gestation and lactation (gestation: $12.8,2.8$ and $4.2 \mathrm{mg} / \mathrm{dl}, \mathrm{SE}=0.80$; lactation: $12.5,0.7$ and 0.2 $\mathrm{mg} / \mathrm{dl}$ for day 1,4 and 7 , respectively $\mathrm{SE}=1.11$ ).

Day 1 and mean plasma urea $\mathrm{N}$ concentrations were not different among dietary treatments (Table 5), in contrast to differences in ammonia $\mathrm{N}$ levels. Plasma urea $\mathrm{N}$ concentration for $4 \mathrm{X}$ does was greater $(\mathrm{P}<0.05)$ on day 1 vs 4 in gestation $(12.2 \mathrm{vs} 9.8 \mathrm{mg} / \mathrm{dl} ; \mathrm{SE}=0.73)$, although the concentration was similar between days in lactation (10.4 and $9.2 \mathrm{mg} / \mathrm{dl}$ for day 1 and 4, respectively; $\mathrm{SE}=2.26$ ). For $8 \mathrm{X}$ does, in gestation plasma urea $\mathrm{N}$ concentration ranked $(\mathrm{P}<0.05)$ day $1>4$ $>7(12.7,9.4$ and $7.0 \mathrm{mg} / \mathrm{dl} ; \mathrm{SE}=0.99)$. However, a different ranking $(\mathrm{P}<0.05)$ of day $1>7>4$ was noted in lactation $(13.1,4.8$ and $8.6 \mathrm{mg} / \mathrm{dl}$ for day 1,4 and 7 , respectively; $\mathrm{SE}=2.19$ ).

Glucose concentration on day 1 was higher $(\mathrm{P}<0.05)$ during gestation than lactation and was similar among supplementation frequencies (Table 5). Glucose concentration on day 1 was similar among supplementation frequencies. Mean glucose concentration was not affected by dietary treatment during gestation, but in lactation was greatest among dietary treatments $(\mathrm{P}<0.05)$ for $8 \mathrm{X}$. Mean glucose concentration and the concentration on day 1 during gestation were higher for litter size 1 vs $2(\mathrm{P}<0.05)$. For $4 \mathrm{X}$, glucose concentration was greater $(\mathrm{P}<0.05)$ in gestation on day 4 than 1 ( 54.5 and $65.2 \mathrm{mg} / \mathrm{dl}$ for day 1 and 4, respectively; $\mathrm{SE}=3.74$ ); however, values were similar during lactation ( 38.8 and $34.0 \mathrm{mg} / \mathrm{dl}$ for day 1 and 4 , respectively; $\mathrm{SE}=5.00$ ). Conversely, glucose concentration during gestation for $8 \mathrm{X}$ was greater $(\mathrm{P}<0.05)$ on day 1 and 4 vs 7 (64.5, 57.2 and $38.3 \mathrm{mg} / \mathrm{dl}$ for day 1, 4 and 7, respectively; $\mathrm{SE}=2.48$ ), but ranked day $7>1>4$ in lactation $(38.3,29.8$ and $93.9 \mathrm{mg} / \mathrm{dl}$ on day 1,4 and 7 , respectively; $\mathrm{SE}=3.25$ ). 


\section{DISCUSSION}

\section{Feedstuff composition}

The high ratio of acid detergent lignin:neutral detergent fibre in prairie hay reflects low potential fibre digestibility, and the $\mathrm{CP}$ concentration indicates need for supplemental CP to achieve acceptable levels of performance by animals with moderate to high nutrient requirements.

\section{Feed intake}

A comparison of forage intake values in the different segments of the experiment indicates little effect of SBM supplementation in gestation compared with a tendency for stimulation later, the magnitude of which was slightly greater with higher nutrient requirements when all does were lactating than earlier. In addition to the possible influence of changing nutrient demands on the effect of supplementation with SBM on forage intake, it is possible that maize supplementation in the second part of the experiment had impact. Cereal grain supplementation of low protein forage can decrease fibre digestion by increasing ammonia used by amylolytic microorganisms, thereby decreasing availability for fibrolytics (McCollum and Horn, 1990). However, based on differences between forage and total intake in the different periods of the experiment, it would not appear that maize supplementation had a marked effect on forage intake, in accordance with the generally lessening of adverse effects of starch supplementation on forage intake as forage quality declines (Horn and McCollum, 1987). Similar total feed intake among 1X, $4 \mathrm{X}$ and $8 \mathrm{X}$ treatments is in agreement with findings of Huston et al. (1999b).

\section{Body weight}

Lower BW loss for supplemented does than for C and similar BW and BW change between $1 \mathrm{X}$ and $4 \mathrm{X}$ agree with reports for other ruminant species (e.g., Huston et al., 1999a,b). Differences in BW between 8X vs 1X and 4X were greater in lactation than gestation, most likely because of higher nutrient requirements in lactation that could have lessened $\mathrm{N}$ available for recycling.

The slightly greater difference in BW between litter sizes on day 120 than 57 reflects higher nutrient demands of nursing two kids than one. Also, that final kid BW was greater for single than for twin kids indicates that nutrient supplies for does with twins was not adequate to support maximal kid growth, although total change in litter BW for twin-kid litters was $6.4 \mathrm{~kg}$ compared with $4.1 \mathrm{~kg}$ for single-kid litters. Similar doe BW between litter sizes after birth is unclear, since total litter birth weight was $4.6 \mathrm{vs} 3.2 \mathrm{~kg}$ for 2 and 1 litter sizes, respectively. 


\section{Mohair and skin follicles}

Much greater mohair fibre diameter on day 58-120 than 1-57 may have been due to shedding observed in some does and presence of medullated fibres, as also suggested by slightly greater SE for days $58-120$ vs $1-57$. Clean fibre growth rates in the $100-\mathrm{cm}^{2}$ patches were fairly low compared with values noted by Litherland et al. (2000), reflecting the low plane of nutrition in the present experiment and high nutrient demands of late gestation and early lactation. Also, the experiment occurred during a part of the year when growth is slightly less than in earlier and later periods (Litherland et al., 2000).

Fibre growth rate and characteristics measured in the present experiment are in general agreement with reports of Morcombe et al. (1988) and Masters et al. (2002), in which frequency of supplementation did not affect wool growth, mean fibre diameter, clean yield and(or) mean staple strength. Likewise, Calhoun et al. (1988) did not alter mohair fleece production or fibre diameter in male Angora goats by supplementing with cottonseed meal every 1, 2, 3, 4 or 5 days. Although variability in diameter along mohair fibres was not determined in the present experiment, the lack of differences among supplementation frequencies in staple strength suggests little or no impact, in contrast to findings of Peterson et al. (1998) with sheep exposed to longer periods of different nutritional planes. It appears that the nutritional plane in this experiment was not low enough, even with the $\mathrm{C}$ treatment, to decrease staple strength through follicle shutdown despite the elevated nutrient needs of gestation and lactation (Schlink et al., 2000). This may be because Angora goats can exhibit greater fibre production per unit BW compared with sheep selected for wool production and, concomitantly, appear to partition nutrients for moderate to high rates of fibre growth regardless of nutrient restriction (Cronjé, 2000).

In some sheep studies (Langlands, 1973; Robards, 1974), long supplementation intervals have increased fibre growth, possibly as a result of shifts in digestion postruminally with high levels of supplements (Masters et al., 2002). Use of SBM in the present experiment may partially explain why a similar response in fibre growth was not observed. Masters et al. (2002) noted lower wool fibre growth for weekly vs daily supplementation with lupin seed, consisting of protein highly degraded in the rumen, but an opposite difference was observed with expeller canola meal, having protein relatively less extensively degraded in the rumen. Soyabean meal protein is fairly high in ruminal degradability, perhaps more similar to lupin seed than expeller canola meal, and concentrations of sulphur-containing amino acids in soyabean and canola meals, and lupin seed are not greatly different.

That mohair fibre growth rate was not different between litter sizes reflects the high priority in nutrient partitioning to fibre growth, with a preference for loss of body energy stores to support greater gestation and lactation nutrient needs of does 
with two kids vs one rather than to sacrifice fibre growth. Nonetheless, even though Angoras partition nutrients to maintain fibre growth, mechanisms seem in place for support of reproductive processes via use of body adipose and lean tissues. However, for acceptable future reproductive performance, a high nutritional plane for does having reared twins would be required given the continued high priority for fibre growth as well as considerable body tissues to be replenished.

\section{Ruminal fluid ammonia $N$ and plasma urea $N$ and glucose concentrations}

Ruminal ammonia N levels were in accordance with level of SBM supplemented and day of sampling relative to the day of supplementation. The observed concentrations suggest that microbial growth and (or) digestion was limited for $\mathrm{C}$ does as well as for does on other treatments during significant periods of supplementation intervals (Miller, 1973; Satter and Slyter, 1974). Similar plasma urea $\mathrm{N}$ levels among treatments on day 1 of the present experiment may be explained by a delayed response (e.g., 6-8 h) to infrequent supplementation. The difference in glucose concentration between gestation and lactation was probably because of greater use for milk synthesis than development of the gravid uterus.

\section{CONCLUSIONS}

Angora does in late gestation and early lactation consuming low quality forage can be supplemented with protein from SBM as infrequently as once every 4 days without adversely affecting BW. Less frequent supplementation, such as once every 8 days, may be as effective as supplementation daily or every 4 days with moderate nutrient requirements of late gestation. However, in early lactation with elevated nutritional demands, supplementation once every 8 days can increase BW loss compared with more frequent supplementation, although nutrient needs as impacted by litter size in this study did not influence BW response to supplementation frequency. Skin and fibre characteristics were not influenced by infrequent supplementation, except for an improvement in fibre growth rate on day 58-120 with daily supplementation compared with no supplementation or supplementation every 4 days. This finding, along with lower BW for $8 \mathrm{X}$ vs $1 \mathrm{X}$ and $4 \mathrm{X}$, suggest a need for frequent supplementation, such as daily, to maintain BW and stimulate fibre production when nutrient demands of Angoras are high during lactation. Does with 2- vs 1-kid litters mobilized tissue energy reserves to provide nutrients for increased needs for gestation and lactation rather than to lessen mohair fibre growth. 


\section{ACKNOWLEDGEMENTS}

Appreciation is expressed to personnel of the farm and laboratory of the E (Kika) de la Garza American Institute for Goat Research, and Dr. C.J. Lupton, Texas A and M University, San Angelo, for assistance in staple strength measurement.

\section{REFERENCES}

AOAC, 1990. Official Methods of Analysis, Association of Official Analytical Chemists. 14th Edition. Washington, DC, pp. 129-130

ASTM, 1988. Annual Book of the American Society for Testing and Materials Standards. Standard Test Method D584: Wool Content of Raw Wool-Laboratory Scale. American Society for Testing and Materials, Philadelphia, PA

Broderick G.A., Kang J.H., 1980. Automated simultaneous determination of ammonia and total amino acids in ruminal fluid and in vitro media. J. Dairy Sci. 63, 64-75

Calhoun M.C., Shelton J.M., Lupton C.J., Baldwin B.C. Jr., Kulmann S.W., 1988. Effect of frequency of feeding protein supplement on mohair production by Angora goats. Research ReportsSheep and Goat, Wool and Mohair. Texas Agr. Exp. Sta. Prog. Rep. 4590

Cronjé P.B., 2000. Nutrient-gene interactions: future potential and applications. In: P.B. Cronjé (Editor). Ruminant Physiology. Digestion, Metabolism, Growth and Reproduction. CABI Publishing, New York, NY, pp. 409-422

Horn G.W., McCollum F.T., II, 1987. Energy supplementation of grazing ruminants. In: M.B. Judkins (Editor). Grazing Livestock Nutrition Conference. University of Wyoming, Laramie, pp. $125-136$

Huston J.E., Engdahl B.S., Bales K.W., 1999a. Supplemental feeding interval for adult ewes. Sheep Goat Res. J. 15 (22), 87-93

Huston J.E., Lippke H., Forbes T.D.A., Holloway J.W., Machen R.V., 1999b. Effects of supplemental feeding interval on adult cows in western Texas. J. Anim. Sci. 77, 3057-3076

Langlands J.P., 1973. Wheat as a survival ration for sheep. 2. The effect of frequency of feeding and formaldehyde treatment on wool production and liveweight change. Aust. J. Exp. Agr. Anim. Husb. 13, 347-350

Litherland A.J., Sahlu T., 1996. A review of factors leading to higher fleece production in Angora compared to down-producing goats. Sheep Goat Res. J. 12, 99-104

Litherland A.J., Sahlu T., Toerien C.A., Puchala R., Tesfai T., Goetsch A.L., 2000a. Effects of dietary protein source on fleece and live weight gain in Angora doelings. Small Ruminant Res. 38, 29-36

Litherland A.J., Toerien C., Sahlu T., Lee P., Goetsch A.L., 2000b. Effects of season on fleece traits of Angora does in the U.S. Small Ruminant Res. 38, 63-70

Littell R.C., Milliken G.A., Stroup W.W., Wolfinger R.D., 1996. SAS System for Mixed Models. SAS Institute Inc., Cary, NC

Masters D.G., Mata G., Liu S.M., Schlink A.C., 2002. Frequency of feeding lupin and canola meal supplements to young sheep influences wool growth and mitotic rate but not staple strength. Aust. J. Exp. Agr. 42, 103-109 
McCollum F.T., Horn G.W., 1990. Protein supplementation of grazing livestock: a review. Prof. Anim. Sci. 6, 1-6

Miller E.L., 1973. Evaluation of foods as source of nitrogen and amino acids. Proc. Nutr. Soc. 32, 79-84

Morcombe P.W., Ralph I.G., Ferguson J., 1988. Frequency of feeding lupin grain supplements to lambing ewes grazing wheat stubble. Proc. Aust. Soc. Anim. Prod. 17, 262-265

Nixon A.J., 1993. A method for determining the activity state of hair follicles. Biotechnol. Histochem. $68,316-325$

Peterson A.D., Gherardi S.G., Doyle P.T., 1998. Components of staple strength in fine and broad wool Merino hoggets run together in a Mediterranean environment. Aust. J. Agr. Res. $49,1181-1186$

Robards G.E., 1974. The effect of infrequent feeding on the wool production of Merino sheep. Proc. Aust. Soc. Anim. Prod. 10, 363-366

Satter L.D., Syter L.L., 1974. Effects of ammonia concentration on ruminal microbial protein production in vitro. Brit. J. Nutr. 32, 199-208

Schlink A.C., Sanders M., Hollis D.E., 2000. Seasonal variation in skin and wool follicle morphology of grazing Merino sheep with high and low staple strength. Asian-Austr. J. Anim. Sci. 13, Suppl. A, 453-456

\section{STRESZCZENIE}

Wpływ częstotliwości podawania śruty sojowej oraz liczebności miotu na wyniki produkcyjne kóz angorskich, żywionych niskiej jakości sianem ląkowym w okresie późnej ciąży i w początkowym okresie laktacji

W stu dwudziestodniowym doświadczeniu (15 okresów po 8 dni) 56 kóz angorskich (43 $\pm 0,7$ $\mathrm{kg}$ początkowej m.c.), z jednym lub dwoma koźlętami w miocie, żywiono niskiej jakości paszą objętościową. Badano wpływ częstotliwości podawania śruty sojowej na wyniki produkcyjne kóz w końcowym okresie ciąży ( $92 \pm 18$ dni po zapłodnieniu) i w początkowym okresie laktacji. Siano łąkowe (5,1\% białka ogólnego i 70\% NDF) podawano do woli, w grupie kontrolnej (C) bez dodatku śruty sojowej (SBM) lub z dodatkiem SBM w dawkach dziennych, stanowiących $0,125 \%$ m.c., codziennie, co czwarty lub co ósmy dzień (grupy 1x, 4X i 8X, odpowiednio). Po wykoceniu dawkę uzupełniono śrutowaną kukurydzę w ilości 0,5 do $1 \%$ m.c.. Wykoty następowały między 7 a 11 okresem doświadczalnym, przy czym około połowa kóz wykociła się przed 58 dniem.

Średnie całkowite pobranie suchej masy paszy przez kozy w ciagu całego doświadczenia było najniższe $(\mathrm{P}<0,05) \mathrm{w}$ grupie $\mathrm{C}$ w porównaniu z pozostałymi 1,$00 ; 1,25 ; 1,24 ;$ i $1,23 \mathrm{~kg} /$ dzień$)$; średnie pobranie paszy objętościowej wynosiło 0,$79 ; 0,97 ; 0,96$ i $0,94 \mathrm{~kg} / \mathrm{dzień}$ w grupach $\mathrm{C}, 1 \mathrm{X}, 4 \mathrm{X}$ i $8 \mathrm{X}$, odpowiednio $(\mathrm{SE}=0,39)$. W 31 dniu doświadczenia m.c. kóz grupy $\mathrm{C}$ była niższa $(\mathrm{P}<0,05)$ niż z pozostałych grup $1 \mathrm{X}, 4 \mathrm{X}$ i $8 \mathrm{X}$ (43,3; 46,0; 46,2 i 45,9 kg, odpowiednio). 57 dnia m.c. kóz z grup C i $8 X$ była niższa $(37,7$ i 39,3 kg; P < 0,05) niż z grup $1 X$ i 4X (41,5 i 41,8 kg, odpowiednio), a w 120 dniu była następująca $(\mathrm{P}<0,05)$ : $\mathrm{C}<8 \mathrm{X}<1 \mathrm{X}$ i $4 \mathrm{X}(31,5 ; 38,5 ; 37,7$ i 34,7 kg, odpowiednio dla $\mathrm{C}, 1 \mathrm{X}$, 4X i 8X). Kozy z pojedynczymi koźlętami były cięższe niż z bliźniętami $(\mathrm{P}<0,05)$ : 57 dnia - 41,5 vs $39,7 \mathrm{~kg}, 120$ dnia - 37,3 vs 33,9 kg. Nie stwierdzono wpływu dodatku SBM ani wielkości miotu na wydajność włókna wełny, średnice oraz wysadność i wytrzymałość wełny. Tempo przyrostu czystego włókna było podobne w grupach między 1 a 57 i 58 a 120 dniem niezależnie od typu wykotu, oraz 


\section{PERFORMANCE OF ANGORA DOES DURING GESTATION AND LACTATION}

między 1 a 57 dniem niezależnie od zastosowanego dodatku paszy. Jednakże od 58 do 120 dnia tempo przyrostu włókna było większe $(\mathrm{P}<0,05)$ u kóz grupy $1 \mathrm{X}$ w porównaniu z $\mathrm{C}$ i $4 \mathrm{X}(0,061$; 0,$089 ; 0,60$ i $0,079 \% \mathrm{~g} / \mathrm{dzien} / 100 \mathrm{~cm}^{2} \mathrm{w}$ grupach $\mathrm{C}$ vs $1 \mathrm{X}, 4 \mathrm{X}$ i $8 \mathrm{X}$, odpowiednio).

W podsumowaniu autorzy stwierdzają, że nieczęste stosowanie dodatku SBM do dawki złożonej z niskiej jakości paszy objętościowej, np. raz na 8 dni, może być tak samo efektywne, jeżeli chodzi o wyniki produkcyjne, jak stosowanie dodatku codziennie lub co 4 dni, przy umiarkowanym zapotrzebowaniu na składniki pokarmowe przez kozy angorskie w późnym okresie ciąży. Jednakże dla utrzymania m.c. i być może stymulowania wzrostu wełny, codzienny dodatek może okazać się konieczny w okresie laktacji, niezależnie od wielkości miotu. 